\title{
The Patterson syndrome, leprechaunism, and pseudoleprechaunism
}

\section{T J DAVID, B W WEBB, AND I R S GORDON*}

From the Department of Child Health, University of Manchester, Manchester; the Paediatric Department, Musgrove Park Hospital, Taunton, Somerset; and the Radiology Department, Bristol Royal Hospital for Sick Children, Bristol.

SUMMARY A bizarre syndrome has hitherto masqueraded as leprechaunism, and although it is $\mathrm{a}_{+}^{\dot{\vec{D}}_{\perp}}$ quite different disorder it has been used as the prototype of leprechaunism in some birth defectsin atlases. It is proposed that this condition is designated the Patterson syndrome and details of a second case are reported. The features of this connective tissue and neuroendocrine disorder include ${ }^{\circ}$ bronzed hyperpigmentation, cutis laxa of the hands and feet, bodily disproportion, severe mentalretardation, and major bony deformities. Radiographs revealed a unique and gross generalised

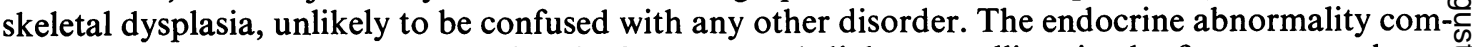
prised hyperadrenocorticism, cushingoid features, and diabetes mellitus in the first case, and pre- $\vec{\oplus}$ mature adrenarche in the second case.

The pathogenesis and aetiology of the Patterson syndrome are unknown, although quantitative ${ }^{-}$ and qualitative abnormalities of mucopolysaccharide excretion were found in the second case.

The condition now known as leprechaunism, or the Donohue syndrome, has had a chequered history. It was first described as dysendocrinism by Donohue in $1948 .{ }^{1}$ Later Donohue and Uchida ${ }^{2}$ reported two sisters under the term leprechaunism. The patients were the product of a consanguineous marriage. The children's growth appeared to have halted at about the 7th month of pregnancy, and both had a very low birthweight. ${ }^{2}$ The elfin-like facies suggested the name leprechaunism.

Subsequently, further cases were described and the features of leprechaunism comprise ${ }^{3-7}$ :

(1) Prenatal growth retardation, lack of adipose tissue, and low birthweight.

(2) Abnormal facies with 'elfin' appearance, prominent eyes, wide nostrils, thick lips, and large ears.

(3) Breast hyperplasia.

(4) Large phallus.

(5) Leydig cell hyperplasia in the male, cystic ovaries, and hyperplasia of the islets of Langerhans.

(6) Hirsutism, body and facial.

(7) Mental retardation.

(8) Severe failure to thrive and death in infancy.

In 1962, Patterson and Watkins ${ }^{8}$ described a 10-month-old baby with what they thought was

* Deceased

Received for publication 16 September 1980 leprechaunism. There were clearly atypical features。

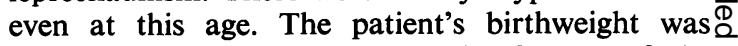
$4250 \mathrm{~g}$, whereas the characteristic feature of the $\overrightarrow{\vec{A}}$ first cases $^{2}$ was marked intrauterine growth retarda- 3 tion; the first two cases had birthweights of $1760 \mathrm{~g} ?$ and $1590 \mathrm{~g}$. The physical features were different. For example, there was marked cutis gyrata of the hands and feet and there was evidence of a generalised skeletal disorder.

In 1969, the same case, by now a grotesque 7-year-old, was reported again by Patterson. ${ }^{9}$ ? Patterson clearly recognised that his patient was unlike cases of leprechaunism and indeed he pre-응 sented the patient for clarification of the diagnosis. $>$ By this time it was evident from the bizarre clinicalo and radiological features that this patient had $\mathrm{a} / \mathrm{N}$ unique syndrome. Unfortunately, this case reporto was entitled 'Leprechaunism', and the confusion has N been perpetuated in several books on birth defects. N

Smith $^{7}$ describes leprechaunism and illustrates it 0 with one of the original cases. No mention is made of cutis laxa or skeletal changes at all. Warkany, ${ }^{10}$ in reviewing leprechaunism, mentions the Patterson $\stackrel{?}{?}$ and Watkins report but points out the atypical 0 nature of the case. Goodman ${ }^{11}$ lists the clinicalo features of leprechaunism without mentioning cutis $\overrightarrow{\mathbb{D}}$ laxa or skeletal changes, but gives the Patterson and $\underset{\mathbb{Q}}{\mathrm{Q}}$ Watkins case as a reference without comment. 
McKusick ${ }^{12}$ published full illustrations of Patterson's patient in a description of cutis laxa, and labelled the condition 'Patterson's leprechaunoid syndrome'. In his book Mendelian Inheritance in Man, ${ }^{13}$ during the discussion of leprechaunism, it is pointed out that follow-up observation of Patterson's case suggested "a different disorder". Gorlin et al l4 $^{14}$ included photographs of Patterson's patient under the general chapter heading of leprechaunism, but like McKusick described this case as having a "leprechaunoid disorder".

However, Patterson's case has been used as the prototype to illustrate leprechaunism in two major texts. In Taybi's Radiology of Syndromes ${ }^{15}$ some of Patterson's radiographs are used to illustrate leprechaunism, although these bizarre skeletal changes are unique to this one case, and the "radiologic manifestations" of this syndrome appear to be based largely on this single report. No less unfortunate is the use of Patterson's patient to illustrate leprechaunism in the second edition of the Birth Defects Compendium, ${ }^{16}$ though curiously no reference or acknowledgement is made to either of Patterson's papers. Furthermore, Maroteaux's atlas quotes some of the findings in Patterson's case as features of leprechaunism. ${ }^{17}$

The condition described by Patterson can now be established as a separate entity with the discovery of a second case.

\section{Case report}

The proband was born on 26.7.68. The mother was aged 22 years and the father 24 years. There was no family history of malformations and no consanguinity. A younger sister, born in 1977, is normal. Pregnancy was normal apart from mild pre-eclampsia and the mother took no drugs. Normal delivery occurred at term, and the birthweight was $4.45 \mathrm{~kg}$. Placental weight was $960 \mathrm{~g}$ and it was described as gritty. The baby was obviously abnormal at birth, and her features have become more striking with age (figs 1,2 ).

C UTIS LAXA

Large redundant folds of skin have been present from birth (fig 2).

\section{HYPERPIGMENTATION}

A marked generalised bronzed hyperpigmentation has been present from birth.

\section{HIR S UTIS M}

Marked hirsutism, present at birth, is now even more apparent. It is largely confined to the limbs (figs 1, 2).

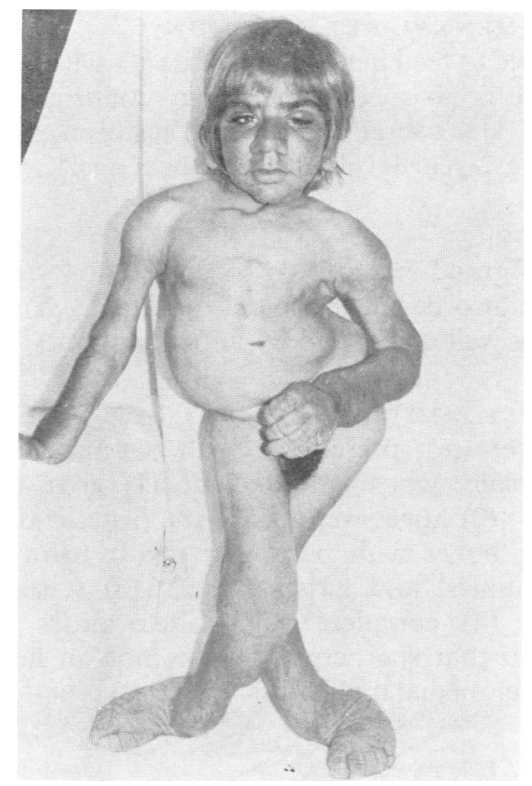

FIG 1 Appearance at 12 years of age.

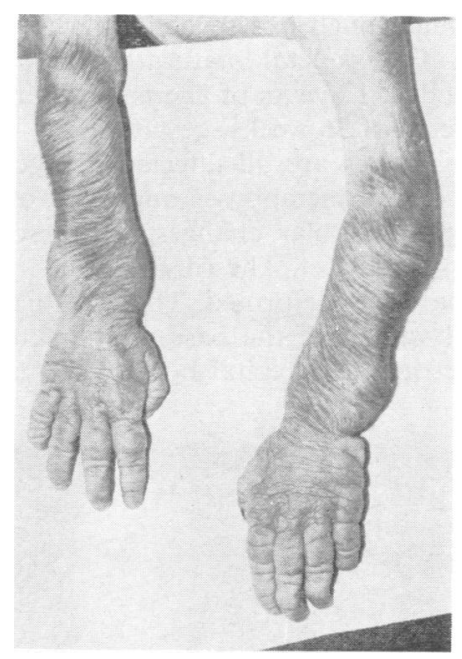

FIG 2 Arms and hands at 12 years of age.

BODILY DISPROPORTION

Noted at birth, this comprises disproportionately large hands, feet, nose, and ears.

\section{PREMAT URE ADRENARCHE}

Pubic hair first appeared at 2 years and at 12 years is at Tanner stage 5 (fig 1). There have been no other signs of puberty and no axillary hair. 


\section{SEVERE MENTAL RETARDATION}

She is able to feed herself and can walk with support, but there is no speech (audiology confirms normal hearing). Her overall functioning has been estimated to be at a 2-year level (chronological age 12 years).

\section{E PILEPSY}

Onset of grand mal epilepsy occurred at 4 years and later she also began to have drop attacks. These are currently well controlled by anticonvulsants.

\section{BONY DEFORMITIES}

These were not present at birth but have become progressively worse and include (1) gross kyphoscoliosis; (2) huge swellings of the distal ends of all the long bones with particular involvement of the knees, ankles, and wrists (fig 2); (3) severe genu valgum; (4) complete valgus deformities of the ankles so that she actually walks not on her heels but on her medial malleoli.

\section{SKELETAL DYSPLASIA}

There is a severe disorder of endochondral ossification affecting both metaphyses and epiphyses. Periosteal ossification and ossification in membrane bones, though much less severely affected, are also abnormal. The skeletal maturation is profoundly retarded and at $\mathbf{1 2}$ years of age is hardly more than that of a fetus of 36 weeks' gestation.

The long bones are all affected identically, with deformity of the metaphyses and ends of the diaphyses (fig 3). Similar changes are present in the hands (fig 4) and feet. The ribs, clavicles, and scapulae are markedly deformed. There is thickening of the cranial vault and the base of the skull, with a large defect in the occipital bone. The maxilla and

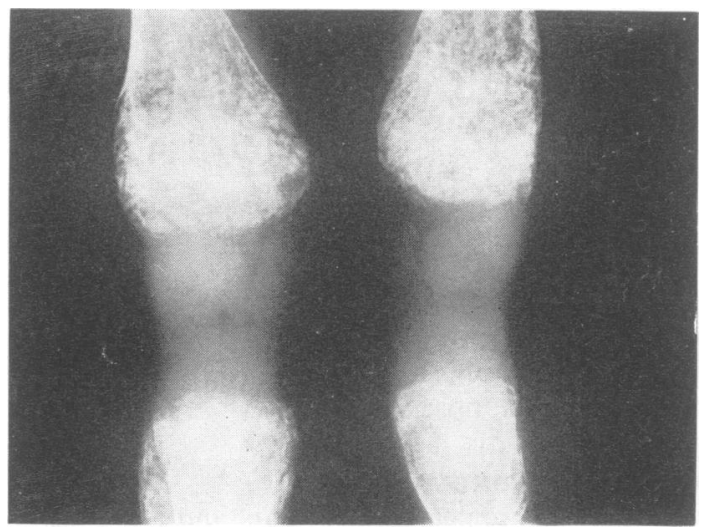

FIG 3 Anteroposterior radiograph of the knees at $7 \frac{1}{2}$ years of age.

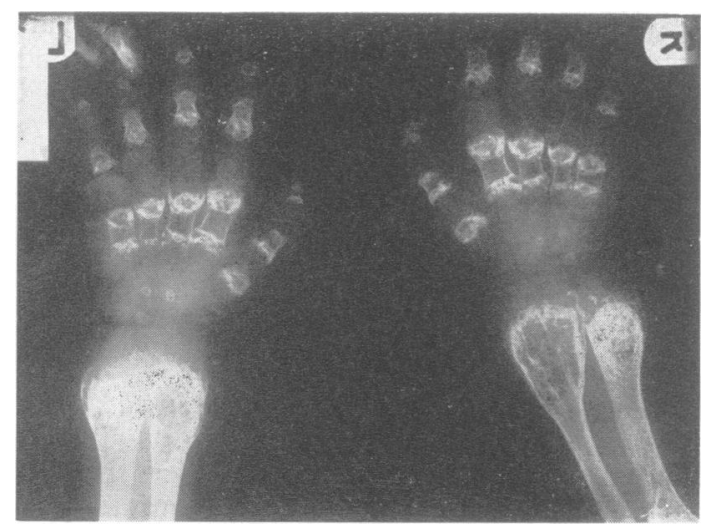

FIG 4 Radiographs of the hands and wrists at 6 years of age.

ethmoid bones are thickened and the mandibular condyles are thickened and deformed.

All the vertebral bodies are deformed, witho irregular and dense end plates. The cervical verte- $\vec{\bullet}$ brae are small and flattened and the thoracic andoo lumbar vertebrae are ovoid. The odontoid process is deficient and the atlas is displaced forwards. Thereo is a severe kyphoscoliosis.

The hips show a combination of progressiveo deformity and failure of ossification of the pubicô bones, the ischia, the triradiate cartilages, and theo margins of the defective sacroiliac joints. There are $\vec{B}$ also rounded defects in the ischia. The acetabulae 3 are deep with flattened irregular roofs (fig 5).

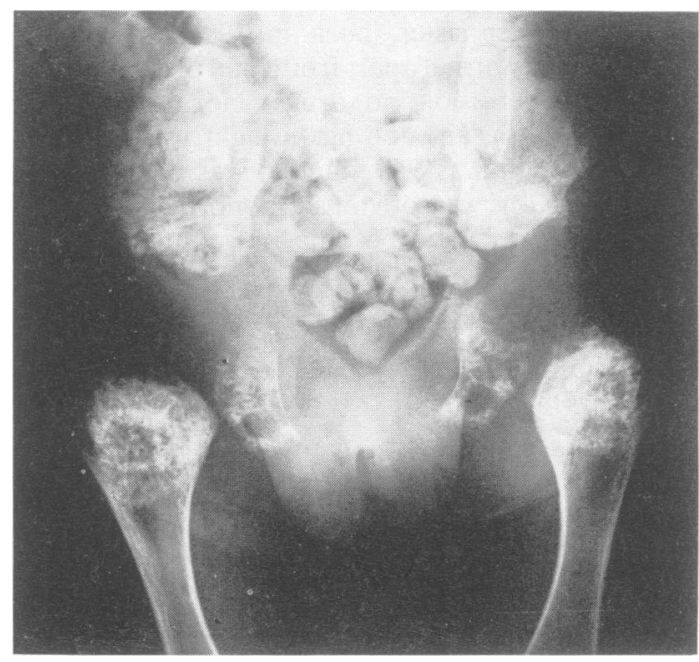

FIG 5 Anteroposterior radiograph of the hips and pelvis at $7 \frac{1}{2}$ years of age. 
Radiological abnormalities were first noted in infancy, but have gradually increased.

\section{DERMATOGLYPHS}

These were abnormal. The total ridge count was 68 . There was a marked appearance of dotted ridges on the palms, and both $t$ triradii were distally displaced (atd angles: left, 53; right, 58). A rare type of vestigial pattern was present on both thenar areas.

\section{Investigations}

Chromosomes, routine haematological and biochemical investigations, and white cell enzymes were normal. There was a bizarre abnormal urinary glycosaminoglycan excretion pattern.

The serum testosterone was less than $0.6 \mathrm{nmol} / \mathrm{l}$ (normal), dehydroepiandrosterone $17 \mathrm{nmol} / \mathrm{l}$ (normal $2 \cdot 6$ to $6 \cdot 3$ ), and androstenedione $10 \mathrm{nmol} / \mathrm{l}$ (normal $0 \cdot 7$ to $1 \cdot 6$ ). The urinary excretion of cortisol derivatives, cortisol precursors, and adrenal androgens was normal.

\section{Discussion}

COMPARISON OF THE TWO CASES

The present case has outlived the previous case by 5 years, and with the progressive nature of the skeletal dysplasia her bony and skeletal deformities have come to dominate the clinical picture.

The cutis laxa, hyperpigmentation, hirsutism, and bodily disproportion are identical in the two cases. Both cases were severely retarded, with epilepsy as an extra feature in the second case.

As far as one can tell from the published radiographs, the features of skeletal dysplasia are almost identical. Dermatoglyphic features are not mentioned in Patterson's case, so comparison is not possible.

The principle difference between the two cases is the nature of the endocrine dysfunction, a prominent feature of Patterson's case with hyperadrenocorticism, cushingoid features, and diabetes mellitus. In the second case the endocrine changes were confined to a premature adrenarche with raised dehydroepiandrosterone and androstenedione levels.

\section{NATURE OF THE DISORDER}

At present the nature of the disorder is unknown, as is its aetiology. The urinary glycosaminoglycan excretion was abnormal both quantitatively and qualitatively (Dr C A Pennock), but the findings do not fit the pattern of any of the known mucopolysaccharidoses and are difficult to assess. Patterson's patient was said to have had normal urinary mucopolysaccharides.

\section{DIFFERENTIAL DIAGNOSIS}

The radiological appearances on their own are very distinctive and are unlikely to be confused with any other bone dysplasia. While there are superficial resemblances to polyostotic fibrous dysplasia, hypophosphatasia, and certain types of metaphyseal chondrodysplasia, ${ }^{18-20}$ the overall picture and natural history of the condition are very different and no difficulty in differential diagnosis should arise.

Not enough is yet known about the Patterson syndrome to list fully the features that clearly distinguish it from leprechaunism, but important distinguishing features of the Patterson syndrome include (1) normal birthweight, (2) bronzed hyperpigmentation, (3) gross cutis laxa of the hands and feet, (4) a unique facial appearance, (5) hirsutism on the limbs, (6) bodily disproportion, (7) bony deformities with a generalised skeletal dysplasia, and (8) survival well beyond infancy.

Dallaire in $1969^{21}$ reported a case initially thought to have the same disorder as Patterson's case, ${ }^{9}$ but later recognised ${ }^{22}$ as a separate entity which was described as "a syndrome of generalised elastic fiber deficiency with leprechaunoid features". Again, there should be no diagnostic confusion with the Patterson syndrome here, the clinical and radiological features being quite different.

In 1977 a unique chondrodysplasia was reported ${ }^{23}$ with some superficial resemblance to the Patterson syndrome, but again both the clinical and radiological features are quite different and there should be no difficulty distinguishing this from the Patterson syndrome.

\section{NOSOLOGY}

Our study of a patient who clearly has the same condition as Patterson's patient indicates that this is a quite distinct entity. This was first pointed out to us by Professor Spranger, who later referred to the condition as 'pseudoleprechaunism'. ${ }^{24}$ As has become evident, the terms leprechaunism, leprechaunoid disorder, and pseudoleprechaunism have done little to clarify a complex situation, and we prefer to designate the condition 'the Patterson syndrome'.

We are indebted to Professor J Spranger for making the diagnosis in the present case, and to Dr C A Pennock for his extensive biochemical investigations. Mrs $\mathrm{C}$ Webb very kindly typed the manuscript.

\footnotetext{
References

1 Donohue WL. Dysendocrinism. J Pediatr 1948;32 :739-48.

2 Donohue WL, Uchida I. Leprechaunism. A euphemism for a rare familial disorder. J Pediatr $1954 ; 45: 505-19$.
} 
${ }^{3}$ Evans PR. Leprechaunism. Arch Dis Child 1955;30: 479-83.

4 Salmon MA, Webb JN. Dystrophic changes associated with leprechaunism in a male infant. Arch Dis Child $1963 ; 38: 530-5$.

5 Summitt RL, Favara BE. Leprechaunism (Donohue's syndrome): a case report. J Pediatr 1969;74:601-10.

6 Rosenberg AM, Haworth JC, Degroot GW, Trevenen CL, Rechler MM. A case of leprechaunism with severe hyperinsulinemia. Am J Dis Child 1980;134:170-5.

7 Smith DW. Recognizable patterns of human malformation. 2nd ed. Philadelphia: Saunders, 1976:356.

8 Patterson JH, Watkins WL. Leprechaunism in a male infant. J Pediatr 1962;62:730-9.

9 Patterson JH. Presentation of a patient with leprechaunism. In: Bergsma D, ed. The First Conference on The Clinical Delineation of Birth Defects. Part IV. Skeletal dysplasias. Birth Defects: Original Article Series. vol 5, No 4. New York: National Foundation-March of Dimes, 1969: 117-121.

10 Warkany J. Congenital malformations. Notes and comments. Chicago: Year Book Medical Publishers, 1971: 159-60.

11 Goodman RM. Genetic disorders among the Jewish people. Baltimore: Johns Hopkins University Press, 1979: 255-9.

12 McKusick VA. Heritable disorders of connective tissue. 4th ed. St Louis: Mosby, 1972: 376-9.

13 McKusick VA. Mendelian inheritance in man. 5th ed. Baltimore: Johns Hopkins University Press, 1978:568-9.

14 Gorlin RJ, Pindborg JJ, Cohen MM. Syndromes of the head and neck. 2nd ed. New York: McGraw-Hill, 1964: 430-2.

15 Taybi H. Radiology of syndromes. Chicago: Year Book Medical Publishers, 1975:142-3.
16 Bergsma D. Birth defects compendium. 2nd ed. London: $\frac{D}{D}$ Macmillan, 1979:644-5.

17 Maroteaux P. Bone diseases of children. Philadelphia: $\overrightarrow{\vec{ज}}$ Lippincott, 1979: 264-5.

18 Wynne-Davies R, Fairbank TJ. Fairbank's atlas of gen-므 eral affections of the skeleton. 2nd ed. Edinburgh: Chur- $\frac{}{\sigma}$ chill Livingstone, 1976:32-3.

19 Spranger JW, Langer LO, Wiedemann HR. Bone dysplasias. An atlas of constitutional disorders of skeletal $\unrhd$ development. Philadelphia: Saunders, 1974:68-9.

20 van Creveld S, Kozlowski K, Pietron K, Vander Valk A. Metaphyseal chondrodysplasia calcificans. A report on $\overrightarrow{0}$ two cases. Br J Radiol 1971;44:773-9.

21 Dallaire L. Discussion of leprechaunism. In : Bergsma D, $\overrightarrow{\vec{\omega}}$ ed. The First Conference on the Clinical Delineation of $\mathscr{D}$ Birth Defects. Part IV. Skeletal dysplasias. Birth Defects: Original Article Series. vol 5, No 4. New York: National Foundation-March of Dimes, 1969:121.

22 Dallaire L, Cantin M, Melancon SB, Perreault G, Potier $\vec{\infty}$ M. A syndrome of generalised elastic fiber deficiency with leprechaunoid features: a distinct genetic disease with an 0 autosomal recessive mode of inheritance. Clin Genet $\rightarrow$ 1976;10:1-11.

23 Zonana J, Rimoin DL, Lachman RS, Cohen AH. A unique chondrodysplasia secondary to a defect in chon- droosseous transformation. Birth Defects: Original Article Series. vol 13, No 3D. New York: Liss, 1977:155-63.

24 Spranger J. 'New' dwarfing syndromes. Annual review of birth defects 1976. Part B. New syndromes. Birth Defects: Original Article Series. vol 13, No 3B. New York: Liss, 1977:11-29.

Requests for reprints to Dr T J David, Booth Hall Children's Hospital, Charlestown Road, Blackley, Manchester M9 2AA. 